OPEN ACCESS

Edited by:

Angel Borja

AZTI, Spain

Reviewed by:

Susana Enríquez,

National Autonomous University of

Mexico, Mexico

José Lino Vieira De Oliveira Costa,

Universidade de Lisboa, Portugal

*Correspondence:

Oscar Serrano

o.serranogras@ecu.edu.au

Specialty section:

This article was submitted to

Marine Ecosystem Ecology,

a section of the journal

Frontiers in Marine Science

Received: 11 December 2016

Accepted: 15 February 2017

Published: 28 February 2017

Citation:

Serrano O, Serrano E, Inostroza K,

Lavery PS, Mateo MA and

Ballesteros E (2017) Seagrass

Meadows Provide 3D Habitat for Reef

Fish. Front. Mar. Sci. 4:54.

doi: 10.3389/fmars.2017.00054

\section{Seagrass Meadows Provide 3D Habitat for Reef Fish}

\author{
Oscar Serrano ${ }^{1 *}$, Eduard Serrano ${ }^{2}$, Karina Inostroza $^{3}$, Paul S. Lavery ${ }^{1,2}$, Miguel A. Mateo ${ }^{2}$ \\ and Enric Ballesteros ${ }^{2}$ \\ ${ }^{1}$ Centre for Marine Ecosystems Research, School of Science, Edith Cowan University, Joondalup, WA, Australia, ${ }^{2}$ Centre \\ d'Estudis Avançats de Blanes-CSIC, Blanes, Spain, ${ }^{3}$ BMT Oceanica Pty Ltd., Wembley, WA, Australia
}

For large fishes, seagrass canopies typically provide a relatively flat habitat on seabeds, but seagrasses in the genus Posidonia can provide additional habitat complexity by forming organic-rich deposits known as mats. Erosional processes can scour channels through the mats, resulting in the formation of escarpments with caves. Here we report that reef fishes, such as groupers, inhabit the caves found within mat escarpments. The characteristics of the cavities are highly variable, ranging from small-elongated holes to deep caves with large entrances. The origin of these caves (biological and/or geological) is unknown, but it is possible that fish behavior enhance their formation. Posidonia seagrass escarpments provide a complex 3D habitat for reef fish that is not provided by typical canopy structure of seagrass. Further studies are required to gain insights into the natural history of seagrass escarpments and their ecological importance.

Keywords: Posidonia, biodiversity, fish ecology, behavior, Mediterranean Sea, Indian Ocean

Seagrass canopies typically provide a relatively uniform habitat on the seabed, which is not suitable for large reef fishes. However, seagrasses in the genus Posidonia can modify bottom bathymetry through vertical plant growth and sediment accumulation, resulting in organic-rich deposits known as mats (Pérès and Picard, 1964; Mateo et al., 1997). Erosional processes can scour channels through the mats, resulting in the formation of 1-3 $\mathrm{m}$ high and up to $500 \mathrm{~m}$ long escarpments (Serrano et al., 2016; Figure 1). Previous studies also reported the presence of blowouts in Thalassia testudinum meadows, consisting of bare areas with an eroding edge that forms a vertical wall with overhanging seagrass roots and rhizomes (Patriquin, 1975; Wanless, 1981; Maciá and Robinson, 2005).

The mechanisms behind escarpment formation can be related to natural processes (e.g., wave action, tidal flow, and hurricanes) or to anthropogenic activities, such as dredging, vessel groundings, and propeller scars (Whitfield et al., 2002). Mat escarpments have been described in shallow and highly productive P. oceanica meadows from the Mediterranean Sea, P. australis meadows from the Indian Ocean (Serrano et al., 2016), and in T. testudinum meadows from the Caribbean exposed to strong wave action (Patriquin, 1975; Wanless, 1981). In Posidonia meadows, the inter-twined remains of seagrass tissues consolidate the sandy substrate, holding together the exposed face of the seagrass escarpment and maintaining a semi-rigid, 3D structure, in which caves are found. This phenomenon is unusual but of ecological importance due to its role as habitat for exclusively reef fish species (Figure 2).

During a routine field trip to monitor seagrass meadows at Shark Bay (Western Australia), we discovered that escarpments supported abundant reef fish assemblages. Caves (up to $\sim 1 \mathrm{~m}^{3}$ ) found throughout mat escarpments were occupied primarily by groupers (Epinephelus coioides, Serranidae), with up to 10 individuals $(30-100 \mathrm{~cm}$ in length) observed in a single 

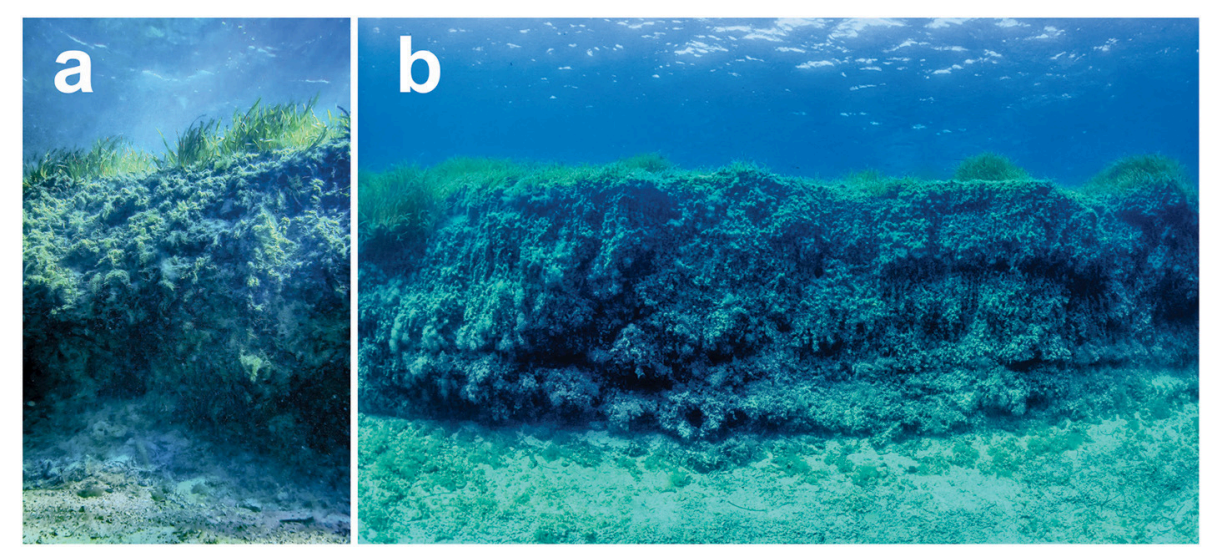

FIGURE 1 | Erosional mat escarpments in seagrass Posidonia meadows. (a) Posidonia australis mat escarpment in Shark Bay, Western Australia $\left(-25.796563^{\circ}, 113.460218^{\circ}\right.$; Indian Ocean). (b) Posidonia oceanica mat escarpment in Es Pujols Cove, Balearic Islands (38.727964 ${ }^{\circ}$ 1.456189 $^{\circ}$; Mediterranean Sea).

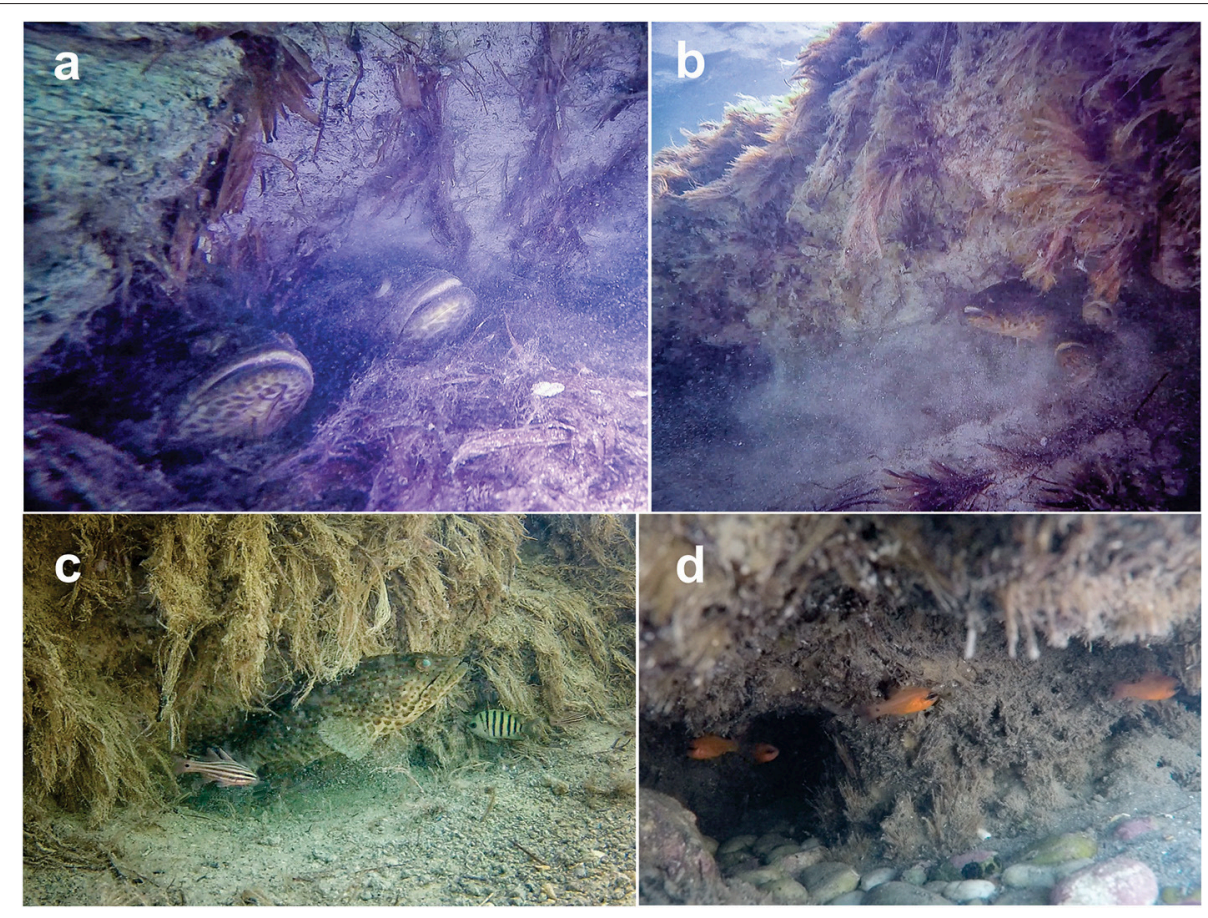

FIGURE 2 | Reef-associated fish inhabiting caves within seagrass mat escarpments. (a-c) Epinephelus coioides, Apogon angustatus, and Abudefduf bengalensis inhabiting caves within Posidonia australis mat escarpment in the Indian Ocean (Shark Bay, Western Australia). (d) Apogon imberbis inhabiting caves within Posidonia oceanica mat escarpment in the Mediterranean Sea (Balearic Islands).

cave (Figure 2 and Supplementary Video 1). Other reefassociated fish found within the escarpment included sea perches (Psammoperca waigiensis, Latidae), cardinalfishes (Apogon angustatus and A. cavitensis, Apogonidae), bengal sergeants (Abudefduf bengalensis, Pomacentridae), and sea chubs (Microcanthus strigatus, Kyphosidae) (Figure 2 and Supplementary Video 1). A similar fish assemblage was observed in reef habitat but not in seagrass canopies nor in unvegetated sand at Shark Bay. Life-time observations made by the authors revealed that mat escarpments in $P$. oceanica meadows are also occupied by reef-associated fish such as scorpionfishes (Scorpaena porcus and S. scrofa, Scorpaenidae), groupers (Epinephelus marginatus and E. costae, Serranidae), cardinalfishes (Apogon imberbis, Apogonidae), brown meagres (Sciaena umbra, Sciaenidae), seabreams (Diplodus sargus, Sparidae), and wrasses (Labrus viridis, L. merula, Symphodus tinca, Labridae) (Figure 2 and Supplementary Video 1). 
In both $P$. oceanica and $P$. australis mat escarpments we found several burrows in the form of cavities inhabited by reef fish. The form, shape, and dimension of the cavities were highly variable, ranging from small-elongated holes to deep caves with large entrances. The process(es) forming these caves (biological and/or geological origin) is unknown, but it is possible that displacement of sediment by fish (i.e., swimming action and/or deliberate digging or burrowing) leads to, or enhances, their formation, as described in other unconsolidated sandy substrates (Mueller, 2015).

Seagrass meadows provide valuable ecosystem services (Green and Short, 2003) and are ecologically important as they provide habitat and shelter for juvenile fish and larval recruitment (Hemminga and Duarte, 2000; Borg et al., 2006; Prado et al., 2009), maintaining high biodiversity, while providing shoreline protection against erosion (Green and Short, 2003), and sequestering carbon (Fourqurean et al., 2012), among others. The ecosystem services provided by seagrass meadows greatly vary among habitats due to biotic and abiotic factors, and in this study we provide evidence of a novel function of Posidonia escarpments, through provision of complex $3 \mathrm{D}$ habitat for reef fish that is not provided by typical canopy structure of seagrass.

Further studies are required to gain insights into the natural history of seagrass escarpments and their ecological importance. Firstly, there is need to report and map additional seagrass escarpments within Posidonia meadows (Serrano et al., 2016) and other seagrass ecosystems worldwide, including T. testudinum meadows in the Caribbean region. Secondly, further research is required to understand the mechanisms of escarpment and

\section{REFERENCES}

Borg, J. A., Rowden, A. A., Attrill, M. J., Schembri, P. J., and Jones, M. B. (2006). Wanted dead or alive: high diversity of macroinvertebrates associated with living and 'dead' Posidonia oceanica matte. Mar. Biol. 149, 667-677. doi: 10.1007/s00227-006-0250-3

Fourqurean, J. W., Duarte, C. M., Kennedy, H., Marbá, N., Holmer, M., Mateo, M. A., et al. (2012). Seagrass ecosystems as a globally significant carbon stock. Nat. Geosci. 5, 505-509. doi: 10.1038/ngeo1477

Green, E. P., and Short, F. T. (2003). World Atlas of Seagrasses. Berkeley, CA: University of California Press.

Hemminga, M., and Duarte, C. M. (2000). Seagrass Ecology. Cambridge: Cambridge University Press.

Maciá, S., and Robinson, M. P. (2005). Effects of habitat heterogeneity in seagrass beds on grazing patterns of parrotfishes. Mar. Ecol. Prog. Ser. 303, 113-121. doi: $10.3354 /$ meps303113

Mateo, M. A., Romero, J., Pérez, M., Littler, M. M., and Littler, D. S. (1997). Dynamics of millenary organic deposits resulting from the growth of the Mediterranean seagrass Posidonia oceanica. Estuar. Coast. Shelf Sci. 44, 103-110. doi: 10.1006/ecss.1996.0116

Mueller, R. J. (2015). Evidence for the biotic origin of seabed pockmarks on the Australian continental shelf. Mar. Pet. Geol. 64, 276-293. doi: 10.1016/j.marpetgeo.2014.12.016

Patriquin, D. G. (1975). "Migration" of blowouts in seagrass beds at Barbados and Carriacou, West Indies, and its ecological and geological implications. Aquat. Bot. 1, 163-189. doi: 10.1016/0304-3770(75) 90021-2 cave formation, including testing the hypothesis of cavities within the escarpment originated by fish behavior, and describe their size and dimension. Finally, there is a need to demonstrate the ecological importance of seagrass escarpments as reef fish habitat, enhancing fish biodiversity and biomass, and their importance for reproduction, predator avoidance and feeding areas, among others.

\section{ETHICS STATEMENT}

The Ethics Committee of Edith Cowan University has approved this study - Project 17297.

\section{AUTHOR CONTRIBUTIONS}

OS: Conceived the manuscript. All authors critically revised and approved the final manuscript.

\section{ACKNOWLEDGMENTS}

This work was supported by the ECU Early Career Research Grant Scheme. OS was supported by an ARC DECRA DE170101524. This is a contribution of the Benthic Ecology Group, 2014SGR120.

\section{SUPPLEMENTARY MATERIAL}

The Supplementary Material for this article can be found online at: http://journal.frontiersin.org/article/10.3389/fmars. 2017.00054/full\#supplementary-material

Pérès, J. M., and Picard, J. (1964). Nouveau manuel de bionomie benthique de la mer méditerranée. Rec. Trav. Station Mar. d'Endoume 31, 1-37.

Prado, P., Romero, J., and Alcoverro, T. (2009). Welcome mats? The role of seagrass meadow structure in controlling post-settlement survival in a keystone sea-urchin species. Estuar. Coast. Shelf Sci. 85, 472-478. doi: 10.1016/j.ecss.2009.09.012

Serrano, O., Lavery, P. S., López-Merino, L., Ballesteros, E., and Mateo, M. A. (2016). Location and associated carbon storage of erosional escarpments of seagrass Posidonia mats. Front. Mar. Sci. 3:42. doi: 10.3389/fmars.2016.00042

Wanless, H. R. (1981). Fining-upwards sedimentary sequences generated in seagrass bed. J. Sed. Res. 2, 445-454.

Whitfield, P. E., Kenworthy, W. J., Hammerstrom, K. K., and Fonseca, M. S. (2002). The role of a hurricane in the expansion of disturbances initiated by motor vessels on seagrass banks. J. Coast. Res. 37, 86-99. Available online at: http:// www.jstor.org/stable/25736345

Conflict of Interest Statement: The authors declare that the research was conducted in the absence of any commercial or financial relationships that could be construed as a potential conflict of interest.

Copyright (C) 2017 Serrano, Serrano, Inostroza, Lavery, Mateo and Ballesteros. This is an open-access article distributed under the terms of the Creative Commons Attribution License (CC BY). The use, distribution or reproduction in other forums is permitted, provided the original author(s) or licensor are credited and that the original publication in this journal is cited, in accordance with accepted academic practice. No use, distribution or reproduction is permitted which does not comply with these terms. 